\title{
The Impact of Alexander's Death on the Greek and Roman World
}

\author{
Ioanna-Soultana Kotsori \\ University of Peloponnese, Faculty of Humanities and Cultural Studies, Kalamata
}

Received 1 October 2018 - Revised 30 November 2018 - Accepted 7 December 2018

\begin{abstract}
Alexander the Great, the king of Macedon, was a significant strategist with successful battles. He became king at the age of 20 years and he fought for 12 years. When he died, the successors of his vast empire wanted to follow his tactics. The early death of Alexander was, in fact, to give the hidden discontents, which could lead to local compromises, a completely different dimension. Alexander's body buried for a few years in Memphis, while later carrying it somewhere near Alexandria. Those who honored Alexander as no one else was the Romans. The Roman emperors pursued his glory and his fame, so they imitated his attitude and his plans. The identification of the tomb of Alexander has some problems and it is worthwhile for further research and study.
\end{abstract}

Keywords: Alexander's tomb, successors, syma, sarcophagus, Roman visits.

\section{Introduction}

Alexander III of Macedon (356-323 BC) or Alexander the Great, originally king of Macedonia, and Leader of the Pan-Hellenic Alliance against the Persian Empire, then owner of an Eastern Empire, Asia and Northwest India, as the successor of the Achaemenids and beyond the three roles, the one who would give him the oracle of Ammon as the son of Jupiter, to whom the dominion of the world belonged (Mosse, 2001: 15). His conquests constituted the foundation stone of the Hellenistic era of the Kingdoms of his successors and descendants. He succeeded in such a short period of time as no other mortal has ever replicated (Yenne, 2010: 89).

Alexander grew up in a kingdom where he was constantly in war. It was his duty to lead the Macedonians in the war, not from afar, but at the forefront of the battle. Alexander has been going for twelve years with insurmountable difficulties and unspeakable risks. It is unmistakable as a mythical hero, amazed by the peoples of the earth. And it harmonizes the power of the weapons with the miraculous property of the Greek spirit, ignorance with education, violence with virtue, provokes the idea of the universality. Thus, it gives humanity a work of unprecedented and beneficial work as a historical event.

He was one of the greatest generals in history, and during the 13 years of his reign (336-323 BC) he captured most of the then-known world (Asia Minor, Persia, Egypt, etc.), reaching its outskirts India and without being defeated in a battle he himself participated in. Alexander's name has survived more than 2,000 years since his death in the imagination of the people of the East and the West as a legendary form until the latest scientific research has received

(C) Authors. Terms and conditions of Creative Commons Attribution 4.0 International (CC BY 4.0) apply. Correspondence: Ioanna-Soultana Kotsori, University of Peloponnese, Faculty of Humanities and Cultural Studies, Department of History, Archaeology and Cultural Resources Management, Kalamata, GREECE. E-mail: ioannakotsori@gmail.com. 
his man and his gigantic work, and he submits this under rigorous criticism and control (Golden, 2011: 18).

\section{Alexander's death}

Alexander III of Macedon was born in Pella around 20 July 356 BC, on the sixth of the month of the Hundredthon, the corresponding Macedonian month of Loyos (Plutarch, Alexander, 3), the same day that Herastratus burned the Temple of Artemis in Ephesus, which the priests felt that that day a great disaster for Asia (Green, 1991: 89).

According to tradition, his genealogy dates back to two central forms of the ancient Greek tradition, that of the half-god Hercules who was the origin of the dynasty of the Argaeon Macedonians, and that of the hero Achilleas, whose son, Neoptolemos, founded the royal house of Molosses, whose member was the mother of Olympiada. The Olympiad had cultivated in Alexandros a tendency towards superstition and deep conviction that he was a descendant of Achilles. Alexander's legendary origins have contributed decisively to shaping his character since the early years of his life, founded the royal house of Molosses, a member of which was his mother Olympiada. Olympiad had cultivated in Alexandros a tendency towards superstition and deep conviction that he was a descendant of Achilles. Alexander's legendary origins have contributed decisively to shaping his character since the early years of his life (Renault, 2001: 35).

The lessons with Aristotle and the new army were the most precious gifts that Philip made to his son. In $338 \mathrm{BC}$, Alexander participated in his first campaign with his father as the head of the cavalry of the partners, in the battle of Chaeroneia (Arrian, III), during which Philip crushed the forces of the Athenians and the Thebans. Alexander was proclaimed king by blame on the same day his father was murdered at the age of twenty. In $334 \mathrm{BC}$ he invaded Asia and never returned to Macedonia, having conquered much of the then-known world.

In the spring of $323 \mathrm{BC}$ arrives at Babylon. On the same day of his arrival, a woman of the people gave birth to a monster. He was a child with a lion's head, a horse's feet and a bull's tail, and dying a few days later. The country's astrologers see this forthcoming death of Alexander, who was born in the constellation of the lion. There are ambassadors waiting for him from all parts of his state and from other countries. Others to congratulate him and crown him as Asian king, others to conquer with him friendship and alliance, such as the Carthusians, the Libyans and the Ethiopians, whose conquest seemed shortly thereafter. But Alexander does not reveal to anyone his future plans. He was making plans for explorations that would include the Caspian (Walbank, 1981: 46). He wants to occupy Arabia and North Africa and for this reason he ordered the construction of a new fleet. In a few days he would leave Babylon for the new campaign.

On the $15^{\text {th }}$ of the Macedonian month of Dessius (31 May), Alexander presented a symposium in honor of Admiral Nearchus in Babylon, in order to prosper him and wish him good luck in exploring the Arabian Peninsula. Late in the evening, Alexander's friend, Thessalos of Midia, called him to continue their fun in his home. Alexander accepted and continued until dawn, but upon his return he felt sick, was washed in his bath and slept until noon.

But after this exhausting symposium with abundant wine, she suddenly fell ill with malignant fever. His state of health was getting worse. He staged his campaign until his health improved. On June 12, he greeted his old Macedonian co-sponsors, who passed one by one from his bed, and at the last hour they asked Alexander to leave his kingdom. His answer is extremely puzzling, "I hold it", that is to say, the strongest (Diodorus, XVII ", 117). An effort to walk in the countryside and get some air speeds up the fatal moment. Silently outdoors in the hands of his courtiers. On 13 June, 323 (which coincides with the $28^{\text {th }}$ of the Macedonian month of Dessius) dies in Babylon, at the age of 33, having reigned twelve years and eight months. 
Today's scientists attribute his death to various causes: others in drink, another in malaria, and another in diastragian ulcer. The most recent version speaks of a rare symptom of typhoid fever called ascending paralysis. If this is true, it must look dead long before it dies, and that explains the fact that the ancient sources report that his body began to decay several days after his death ${ }^{1}$. They say that, before leaving the river, Alexander raised in memory of his campaign a magnificent monument, the traces of which were never found. They consisted of 12 altars, dedicated to the gods of Greece and the East, and a brass obelisk that simply wrote: "Here Alexander stopped”.

\section{Alexander's tomb}

The news of his death caused sadness throughout the world of the East and for centuries honored his memory by recognizing the work he had done. In Africa and Asia, they held magnificent ceremonies in his memory, and in India, every anniversary of his death was consumed by the Sanctuary of the temples as a sign of honor. In Arabic historians Ya'qūbì, Mas'ūdì and Tha'âlibì there is a reference to the short reasons spoken by philosophers from all over the world in front of dead Alexander. Sa'ìd b. al-Biārīq tells that Philemon, the Alexander the Vizier, ordered each of the wise men to utter a melodious song in the form of melody, which would be a palliative reason for the ruling higher classes and a moral lesson for the people (Kraemer, 1992: 148-150).

The Greeks, on the contrary, did not cause the early loss of sorrow, but a sense of relief, especially to the Athenians, who believed that the road is now free to become the first power among the Greek city-states. Perhaps they were also in the succession of the imperious empire. Alexander was treated just as every great Greek, the people did not forgive his success, but he tried to subdue his creations.

According to the testimonies, his body was cleaned and placed in a glass coffin full of honey. His body was embalmed, without it being a Macedonian custom, as was the incineration of the dead. The decision on racking probably came from the need to persuade the royal court, and probably the mother Olympiad that Alexander was not assassinated by assault or poisoning. After his death there was a serious problem with his burial. It is claimed that before he dies, he wanted to be buried in the desolate Siouah, next to the famous temple of Ammon Ra, whom he had visited and believed to be his origin, but his wish was not accepted.

The formal procession of the transfer took place two years later, so it took the way back to Greece to be buried in Macedonia. It is unknown the burial, since it is supported the view that Ptolemy, his close friend, intervened and took Alexander's body and buried it for a few years in Memphis (Pausanias, 1.6), while later carrying it somewhere near Alexandria, hoping to legalize his power in Egypt at the beginning of his dynasty (Saunders, 2006: 35, 62). While Ptolemy held Alexander's body, Perdiccas and Eumenes held in their possession the chest, the diadem and the royal scepter of Alexander (Saunders, 2006: 41).

According to the Pseudo-Cleisthenes novel, when the inhabitants of Memphis were informed that the procession is approaching, they came out to pretend and accompany it to the city. The archbishop of the Memphis sanctuary urged them not to bury Alexander there, but to Raquita $^{2}$, adding that where else and if the tomb is buried, that city will always experience riots and suffer fights and wars. Immediately afterwards, Ptolemy leads the procession to Alexandria,

\footnotetext{
${ }^{1}$ Bengtson claims that Alexander died in Babylon on 10 June 323 BC. As far as the causes of his death are concerned he claims that he died due to endemic fever, but the other cause may have been pneumonia or poisoning (Bengtson, 1988: 315).

${ }^{2}$ The town of Rakotis was a great necropolis attributed to Pharao, which included Nectanavo's tomb and his sarcophagus (Chugg, 2002: 14).
} 
establishing a tomb in the sanctuary, called the "Syma of Alexander" ("Syme of Alexander" in the Syriac translation), and buried there the relic of King Alexander (Errington, 1976: 145).

Alexandria of Egypt is Alexander's burial site and Alexander's Short Life. The Syrian Alexander novel adds that as the dead body of Alexander arrived in Memphis, all residents of the area went to see him, accompanied him even with all types of music. They also praised Alexander calling him the god of Sesonchosis and ruler of the world. They also welcomed him and said they were welcome. They held Alexander's body in Memphis for twelve days, and every day they sang chanting chants for him. The inhabitants of Memphis wanted to keep Alexander's body there. Yet though all their desire, the priests of Serapis told that the body of Alexander was to be in the city, which he built. In the end, Ptolemy blamed Alexander for Alexandria. This place, according to the Syrian translation, is so far called "The tomb of Alexander" - "Syme Alexander" (Stoneman, 1992: 111).

The identification of the tomb of Alexander poses some problems. Normally, in the Greek cities the founder's tomb was on the market. Maybe initially Ptolemy had to raise him there. However, Strabo, who wrote in the 2nd century AD, places him in Sigma, a burial monument, which sheltered not only Alexander, but also the first Lagidas, which was in the palace district. It has been hypothesized that the tomb of the conqueror was moved in the years of the reign of Ptolemy IV (Mosse, 2001: 216).

In the following centuries and until the end of the Ptolemaic Dynasty in Egypt, there will be few indirect references to the Alexander House. This coffin is also mentioned by Strabo and Kourtio Roufio, where they mention that in 89 to 90 BC, on Ptolemy I, the gold coffin was removed to melt for the production of coins and the repayment of the king's debts, and how was replaced by a glass or crystal, an act that was considered sacrosanct by the people of Alexandria (Strabo, 17.1.8). The same was done by the last Greek emperor of the Ptolemaic dynasty, Cleopatra Z, who, in its attempt to reconstruct a new fleet for the war needs against Rome, removed a large quantity of gold from the grave (Chugg, 2007: 94).

The marble tombstone called Alexandros Sarkophagus in the archaeological museum of Constantinople is not related to Alexander himself and is considered to be that of Abdalonym, the local king of Phenicia (about the limits of today's Lebanon), with a more modern version claiming that it is that of Mazakos, a Persian governor of Babylon.

\section{The impact of his death on the Greek world}

The death of Alexander caused great sorrow to the conquered and non-peoples of the then-known world. In showing gratitude for the work he did, he honored his memory for centuries. In Spain he wore his statues. In Africa and Asia they organized magnificent ceremonies. In India, every anniversary of his death, the Temple Fire of temples went out, a sign of the highest honor.

The premature death of Alexander makes the historical crisis difficult, to extend his work to various phases, showing his gigantic political and economic work. Alexander, as the ancient writers present him, is the genius of the army, who remained the model of great later physiognomists, such as Hannibal, Scythian of the African, Pompey, Caesar, Trajan, Constantine and Julian, and Napoleon's younger years.

But from the measures he has taken for the better organization of his loyal state, his financial administration and the single monetary system he has applied, it is possible to conclude that death actually took place at that time, which would have been the starting point a new period in Alexander's life, during which he would experience great political qualities of the genius commander. If his life was extended for a few years, it would probably be that he would bring unity into his vast state, for it would have made it possible to assemble his dissimilar elements. 
When Alexander lived, his own citizens viewed him differently: in the Macedonians, despite the Persian customs in the yard, the king remained, whom they proclaimed after the death of Philip. The other Greeks were the principal, rather than the ally, the one who was imposed as leader in the Corinthian Alliance. In the Asians he was the successor of the Achaemenids, while in Egypt the successor of Pharaoh. So the cohesion of the state of Alexander depended on a single man, who was Alexander himself. But this was at the same time the impossible point in the whole body of the Macedonian king's empire, as it was after his death.

The early death of Alexander was, in fact, to give the hidden discontents, which could lead to local compromises, a completely different dimension. The absence of power in Macedonia, as in Asia, left Greeks to hope that the time has come for the recovery of independence. Especially for the Athenians, the death of Alexander caused great relief, believing that the way was liberated for the recapture of the first position among the Greek city-states, perhaps for the succession of his glorious empire (Mosse, 2001: 94).

We can easily imagine that the sudden death of Alexander surprises his environment. In the conflicts in Babylon, which contradicted the successors, the image of Alexander was used by both of them. From the beginning Perdikkas succeeded in taking control of the situation by claiming that he had taken from the hands of dying Alexander a ring that made him an "executor of the will". Perdikas had built a heavily decorated arcade that reminded Alexander's victories and presented the idea of his deposition. The transfer had to pass through Egypt, enabling Ptolemy to become the ruler of the royal relic buried in Memphis, before transferring it to Alexandria, where it was laid siege and struggles around his grave. Thus, the gentleman of Egypt laid himself under the protection of the "god" Alexander (Mosse, 2001: 237-8).

Another successor, Eumenes, the former Archbishop, also gives an example of the use of this deceased Alexander. During his struggle against Antigonus he made his meetings in a tent where an empty throne was placed, symbolizing the presence of the king. Plutarch in "Bio Eumenes" explains how he thus wanted to secure the obedience of his soldiers, for whom he was afraid of joining Antigonus (Plutarch, Eumenus, 13, 5-6).

But slowly, as a balance was struck between successors, Alexander's memory ceased to be the mandatory reference. After the young Alexander D left the middle and the successors accepted it and then took the title of the king, it is obvious that the new gentlemen of the former Alexander Empire had resigned from their reconstruction and for this reason they ceased to invoke the protection of its founder (Mosse, 2001: 239).

A few centuries after his death, the Roman emperor Augustus expressed his astonishment that "Alexander did not consider the work of the organization of the state he had built more important than his conquest”. But Alexander's great passion was not governance but conquest.

\section{The visit of the tomb of Alexander by the Roman emperors}

Those who honored Alexander as no one else was the Romans. They called him the First Mega. They placed statues in the countries they occupied. The Romans imitated his ways, even his blonde, as well as the slight inclination of his head to the side. They worshiped his tomb already transferred to the communal mausoleum in Alexandria, when King Ptolemy IV Philopator (221-204 BC), the so-called Sign-House. The exact location of the mausoleum is not clear, as the ancient sources are enigmatic and have varied interpretations, while archaeological testimonies are virtually nil (Chugg, 2007: 175).

The first emperor who visited the tomb of Alexander was Julius Caesar in 48 BC, who, ignoring the other eponymous monuments of Alexandria, expressed the desire to see only the 
grave of Alexander. Plutarch says that Caesar recalls the comparison with Alexander and reads a book about Alexander, tells his friends that he admires him that at his age Alexander had a vast empire while he did nothing. The sources say he gets tearful and when his generals ask him why he crys, he says that "what Alexander did to his 33 years did not do all my life" (Plutarch, Caesar, $11,5^{-6) \text {. }}$

Augustus, after the capture of Alexandria, placed a golden wreath on Alexander's tomb in Alexander's tomb and scattered flowers. When Octavian was asked by his leaders if he wanted to see the tombs of the Ptolemy, he replied that he came to see a king and not dead. A similar reference to Octavian's visit to the grave of Alexander is also made by Dion Cassius (51.16.5), who reports that the emperor "broke" a section of Alexander's nose when he tried to embrace him (Chugg, 2007: 95). According to Sweetwater, Roman Emperor Caligula has removed objects from the tomb of Alexander, including his chest (Gaius Souitonius, 4.52.1), believing that he is a redeployment of the great army commander (Saunders, 2006: 83; Chugg, 2007: 99).

Emperor Hadrian, who was a devotee of ancient Greece, went to 130 AD in Egypt and visited Alexandria by making an impressive entrance to the city, as he was driving a chariot that was hauled by four horses (quadriga). The warm welcome he received from the citizens of Alexandria influenced Hadrian, who gave money for renovations and restorations of buildings and statues. Although in ancient sources there is no mention of a visit to the grave of Alexander, there is a great chance he has visited him, a conjecture that can rely on the way he celebrated his visit to the city, where he cut separate coins depicting him Alexander (Saunders, 2006: 83-4).

Another Roman Emperor who visited Alexandria and the Signal-House was Septimius Severus in 199-200 AD. According to Dion Cassius (76.13.2), Septimius arranged to seal the entrance to the grave of Alexander, while at the same time in the tomb he placed a series of books (papyri) containing mystic and magic texts (Chugg, 2007: 106). According to sources, the Roman emperor Caracalla, son of Septimios Severus, was the last emperor to visit Alexandria and SignHouse in $215 \mathrm{AD}$ (Chugg, 2007: 106). Herodianus says (4.8.9) that when Caracalla entered Alexandria, accompanied by his army, he went to the temple first, where he sacrificed many oxen and filled the altars with incense. Leaving the temple he went to the grave of Alexander, removed the royal mantle, his rings with the gems, along with everything else he valued and placed on the grave. The visit of Caracalla is the last safe mention of the tomb in the written sources.

After the visit of Caracalla (215 AD), the ancient sources make no mention of Alexandra's Signal-House located in Alexandria. The cause of the silence of the sources may have been the destruction of the complex containing the tombs of the Ptolemaic and Alexander, however, due to lack of information from the sources, but mainly because of the lack of archaeological evidence, the views differ among modern scholars, exact time period that happened.

Undoubtedly, the most significant change in Alexandria was the destruction of the luxurious Vrouhion area in the northeastern part of the city (around 262 AD). In this area was the palace of the Ptolemies, while during the Roman domination, became the headquarters of the Roman ruler of the city. However, the area suffered irreparable damage during the siege of the city from Aurelius, in 272 AD (Haas, 1997: 340). The grave may have been destroyed and perhaps even plundered during this turbulent period that ravaged Alexandria.

\section{Conclusions}

However, another testimony by Ammianus Marcellinus (22.11.7) is believed by several scholars that the tomb of Alexander existed in the $4^{\text {th }} \mathrm{c} . \mathrm{AD}$, as he mentions that a bishop named Gregorius, passing by the goddess of the Tchaikis temple in Alexandria, wondered, "How long will this tomb stand upright?” something some believe is about Alexander's grave (Signal-House) 
(Chugg, 2007: 118). Also, Ammianus Marcellinus (26.10.15-19) reports that in 365 AD, just four years after the incident with Bishop Gregory, Alexandria was hit by a devastating tsunami (tsunami) caused by a major earthquake between Crete and Egypt. Due to this fact, the earthquake in combination with the tidal wave may have been the cause of the destruction of the tomb (Sign-House) of Alexander (Chugg, 2007: 120).

Moreover, the reference of John Chrysostom (581), patriarch of Constantinople, to the election of Alexander as the 13th member of the Olympian gods, but also to his grave, is considered as an element that he had some prior knowledge of the Sign-House, which implies that the tomb of Alexander might have existed in the $4^{\text {th }} \mathrm{c}$. AD (Chugg, 2007: 113). Shortly afterward, at 400, John Chrysostom in B to the Corinthian letter asks the question of where the grave of Alexandros in Sigma is located (which is the case of Alexander the Great, show me), which is a strong indication that the site of the tomb is no longer known.

However, there is another part of the Christian tradition where Saint Sisko, who lived in the $4^{\text {th }}$ and $5^{\text {th }}$ centuries and died in $429 \mathrm{AD}$, is portrayed in a number of various hagiographic performances to conquer the tomb of Alexander in Alexandria. The show with the tomb probably appeared later in the $15^{\text {th }}$ century, but it is unknown whether it is a historical testimony or a symbolic representation.

According to the above, it appears that the tomb of Alexander (Signal-House) was destroyed between $262 \mathrm{AD}$ and $365 \mathrm{AD}$, as the various controversies that occurred in Alexandria in the late 3 rd cent. $\mathrm{AD}$ there remains a strong possibility of damaging the tomb, as well as the combination of the earthquake and the catastrophic tidal wave that hit the city in $365 \mathrm{AD}$ (Chugg, 2007: 125).

\section{Acknowledgements}

This research did not receive any specific grant from funding agencies in the public commercial, or not-for-profit sectors.

The author declares no competing interests.

\section{References}

Bengtson, H. (1988). History of Greece from the beginnings to the Byzantine era. University of Ottawa Press.

Chugg, A. (2007). The quest for the tomb of Alexander the Great. AMC Publications.

Chugg, A. (2002). The sarcophagus of Alexander the Great? G\&R. 49.1. p. 8-26.

Errington, R. M. (1976). Alexander in the Hellenistic world. In: E. Badian (ed.), Alexandre le Grand: Image et Réalité (141-120). Geneva: Fondation Hardt, Entretiens 22.

Green, P. (2007). Alexander the Great and the Hellenistic age. Phoenix. London

Haas, C. (1997). Alexandria in late antiquity: Topography and social conflict. The Johns Hopkins University Press. Baltimore.

Golden, P. (2011). Central Asia in world history. Oxford: Oxford University Press.

Kraemer, J. L. (1992). Humanism in the renaissance of Islam. The cultural revival during the Buyid age. London. 
I.-S. Kotsori - The Impact of Alexander's death on the Greek and Roman World

Mosse, C. (2001). Alexandre. La destinée d'un mythe. Paris: Payot.

Renault, M. (2001). The nature of Alexander the Great. Penguin.

Saunders, N. J. (2006). Alexander's tomb: The two-thousand year obsession to find the lost conqueror. New York: Basic Books.

Stoneman, R. (1992). Oriental motifs in the Alexander romance. Antichthon 26.

Walbank, F. (1981). Hellenistic world. Harvard University Press.

Wood, M. (2001). In the footsteps of Alexander the Great: A journey from Greece to Asia. University of California Press.

Yenne, B. (2010). Alexander the Great: Lessons from History's undefeated general. Palmgrave McMillan. 